Jurnal Indonesia Sosial Teknologi: p-ISSN: 2723 - 6609

e-ISSN : 2745-5254

Vol. 2, No. 4 April 2021

\title{
KINERJA KPU KABUPATEN SINTANG DALAM PEMUTAKHIRAN DATA DAN PENYUSUNAN DAFTAR PEMILIH PEMILIHAN GUBERNUR DAN WAKIL GUBERNUR KALIMANTAN BARAT TAHUN 2018
}

\section{Supranto}

Program Pascasarjana Universitas Terbuka

Email: asyraafi.stg@gmail.com

\section{Abstract}

Permanent voter list (DPT) has always been a crucial point in the success of the election process or election. The quality of the DPT depends very much on how the Regency Election Commission implements regulations that have been set by the Indonesian Election Commission and the Provincial Election Commission. To implement this regulation requires good performance from all elements of the election organizer. The performance of the Sintang Regency Election Commission in updating the data and preparing the voter list for the Election of the Governor and Deputy Governor of West Kalimantan in 2018 is very strategic in realizing a quality election. The results of this study showed that the quality of the Permanent Voter List (DPT) in the Election of the Governor and Deputy Governor of West Kalimantan in 2018 in Sintang District was already good. This was indicated by voter participation which reached $89 \%$. The process of updating the data and compiling the voter list was carried out according to the schedule set by the West Kalimantan Provincial Election Commission which was guided by Election Commission Regulations. Sintang Regency Election Commission initiative in resolving existing problems in the field was quite good, so that all stages could be carried out properly. The ability of Sintang Regency Election Commission in updating voter data needs to be improved, especially for PPDP and PPS, because they are the spearhead in updating data and compiling voter lists. Sintang Regency Election Commission had built intensive communication with all stakeholders so that the process of updating data and preparing voter lists had run well. The conclusion of this study is the performance of the Sintang Regency Election Commission in updating the data and preparing the voter list for the Election of the Governor and Deputy Governor of West Kalimantan in 2018 viewed from the five aspects studied were quite good.

Keyword: voter list; performance; election commission.

\footnotetext{
Abstrak

Daftar Pemilih Tetap (DPT) selalu menjadi titik krusial dalam kesuksesan penyelenggaraan pemilu atau pemilihan. Kualitas DPT sangat tergantung bagaimana KPU Kabupaten dalam mengimplementasikan regulasi yang sudah ditetapkan oleh KPU RI dan KPU Provinsi. Untuk mengimplementasikan regulasi ini diperlukan kinerja yang baik dari semua unsur penyelenggara pemilihan. Kinerja KPU Kabupaten Sintang dalam pemutakhiran data dan penyusunan daftar
} 
pemilih Pemilihan Gubernur dan Wakil Gubernur Kalimantan Barat Tahun 2018 merupakan hal yang sangat strategis dalam mewujudkan pemilihan yang berkualitas. Tujuan penelitian ini adalah untuk mengetahui kinerja KPU Kabupaten Sintang dalam pemutakhiran data dan penyusunan daftar pemilih yang dilihat dari aspek: (1) kualitas (quality), (2) ketepatan (promptness), (3) inisiatif (intiative), (4) kemampuan (capability), dan (5) komunikasi (communica-tion). Hasil penelitian menunjukkan bahwa kualitas Daftar Pemilih Tetap (DPT) pada Pemilihan Gubernur dan Wakil Gubernur Kalimantan Barat Tahun 2018 di Kabupaten Sintang sudah baik. Hal ini ditunjukkan dengan partisipasi pemilih yang mencapai $89 \%$. Proses pemutakhiran data dan penyusunan daftar pemilih dilaksanakan sesuai jadwal yang telah ditetapkan oleh KPU Provinsi Kalimantan Barat yang berpedoman pada Peraturan KPU. Inisiatif KPU Kabupaten Sintang dalam menyelesaikan persoalan yang ada di lapangan sudah cukup baik, sehingga semua tahapan dapat dilaksanakan dengan baik. Kemampuan KPU Kabupaten Sintang dalam pemutakhiran data pemilih perlu ditingkatkan, terutama untuk PPDP dan PPS, karena merekalah ujung tombak dalam pemutakhiran data dan penyusunan daftar pemilih. KPU Kabupaten Sintang telah membangun komunikasi yang intensif dengan semua stakeholder sehingga proses pemutahiran data dan penyusunan daftar pemilih berjalan dengan baik. Kesimpulan dari penelitian adalah kinerja KPU Kabupaten Sintang dalam pemutakhiran data dan penyusunan daftar pemilih Pemilihan Gubernur dan Wakil Gubernur Kalimantan Barat Tahun 2018 dilihat dari kelima aspek yang diteliti sudah cukup baik.

Kata kunci: daftar pemilih; kinerja; komisi pemilihan umum

\section{Pendahuluan}

Kinerja berasal dari kata performance. Ada pula yang memberikan pengertian performance sebagai hasil kerja atau prestasi kerja, namun kinerja mempunyai makna yang lebih luas, bukan hanya hasil kerja termasuk bagaimana proses pekerjaan berlangsung (Wibowo, 2014). Kinerja dapat merupakan penampilan baik individu maupun kelompok kerja personil. Penampilan hasil kerja tidak terbatas pada personil yang memangku jabatan fungsional maupun struktural di dalam organisasi (Ilyas, 2012).

Kinerja Komisi Pemilihan Umum Kabupaten Sintang dalam Pemutakhiran Data dan Penyusunan Data Pemilih Pemilihan Gubernur dan Wakil Gubernur Kalimantan Barat Tahun 2018 dapat diukur dengan melihat kualitas data yang dihasilkan dari seluruh proses yang dilaksanakan oleh KPU Kabupaten Sintang dan jajarannya dalam pemutakhiran data dan penyusunan daftar pemilih berdasarkan regulasi yang sudah ditetapkan, yaitu Peraturan Komisi Pemilihan Umum Nomor 2 Tahun 2017 tentang Pemutakhiran Data dan Penyusunan Daftar Pemilih dalam Pemilihan Gubernur dan Wakil Gubernur, Bupati dan Wakil Bupati, dan/atau Walikota dan Wakil Walikotadan Keputusan Komisi Pemilihan Umum Provinsi Kalimantan Barat Nomor: 18/ HK.03.1Kpt/61/Prov/VIII/2017 tentang Pedoman Teknis Pemuktahiran Data Pemilih dalam Pemilihan Gubernur dan Wakil Gubernur KalimantanBarat Tahun 2018. 
Kinerja Komisi Pemilihan Umum (KPU) Kabupaten Sintang dalam Pemutakhiran Data dan Penyusunan Daftar Pemilih Pemilihan Gubernur dan Wakil Gubernur Kalimantan

Dari pelaksanaan pemutakhiran data dan penyusunan daftar pemilih dalam Pemilihan Gubernur dan Wakil Gubernur Kalimantan Barat Tahun 2018 di Kabupaten Sintang yang dilaksanakan oleh KPU Kabupaten Sintang beserta jajarannya diketahui data sebagaimana tabel berikut:

Tabel 1.

Perbandingan Jumlah DPT Pemilihan Bupati dan Wakil Bupati Sintang Tahun 2015, DP4,DPS, dan DPT Pemilihan Gubernur dan Wakil Gubernur Kalimantan Barat Tahun 2018

\begin{tabular}{llrrrr}
\hline No. & \multicolumn{1}{c}{ KECAMATAN } & DPT 2015 & DP4 2018 & DPS 2018 & DPT 2018 \\
\hline 1 & AMBALAU & 10.331 & 10.745 & 9.012 & 8.937 \\
\hline 2 & BINJAI HULU & 9.745 & 9.382 & 9.724 & 8.966 \\
\hline 3 & DEDAI & 23.786 & 20.013 & 21.947 & 21.237 \\
\hline 4 & KAYAN HILIR & 22.120 & 18.918 & 20.844 & 20.274 \\
\hline 5 & KAYAN HULU & 19.299 & 16.917 & 17.840 & 17.206 \\
\hline 6 & KELAM PERMAI & 12.227 & 12.506 & 11.733 & 12.430 \\
\hline 7 & KETUNGAU HILIR & 15.301 & 15.364 & 14.871 & 15.173 \\
\hline 8 & KETUNGAU HULU & 16.998 & 14.369 & 14.843 & 14.660 \\
\hline 9 & KETUNGAU TENGAH & 20.330 & 18.805 & 20.740 & 19.936 \\
\hline 10 & SEPAUK & 37.701 & 35.335 & 39.711 & 35.825 \\
\hline 11 & SERAWAI & 17.959 & 17.141 & 17.692 & 16.998 \\
\hline 12 & SINTANG & 48.043 & 49.687 & 42.953 & 43.121 \\
\hline 13 & SUNGAI TEBELIAN & 24.222 & 23.352 & 23.078 & 22.825 \\
\hline 14 & TEMPUNAK & 21.038 & 20.565 & 21.129 & 20.911 \\
\hline & JUMLAH & $\mathbf{2 9 9 . 1 0 0}$ & $\mathbf{2 8 3 . 0 9 9}$ & $\mathbf{2 8 6 . 1 1 7}$ & $\mathbf{2 7 8 . 4 9 9}$ \\
\hline & Sumber: Subbagian Program dan Data KPU Kab. Sintang & &
\end{tabular}

Dari data di atas, dapat dilihat bahwa terjadi penurunan yang signifikan dari data pemilih dimana untuk Pemilihan Bupati dan Wakil Bupati Sintang Tahun 2015 sejumlah 299.100 pemilih menjadi 278.499 pemilih pada Pemilihan Gubernur dan Wakil Gubernur Kalimantan Barat Tahun 2018. Untuk itu, peneliti memaparkan bagaimana kinerja Komisi Pemilihan Umum Kabupaten Sintang dalam Pemutakhiran Data dan Penyusunan Daftar Pemilih Pemilihan Gubernur dan Wakil Gubernur Kalimantan Barat Tahun 2018. 
Penelitian ini ditujukan untuk menggambarkan dan menganalisis kinerja Komisi Pemilihan Umum Kabupaten Sintang dalam Pemutakhiran Data dan Penyusunan Daftar Pemilih Pemilihan Gubernur dan Wakil Gubernur Kalimantan Barat Tahun 218.

Beberapa penelitian yang pernah dilakukan berkaitan dengan kinerja KPU antara lain (1) Penelitian (Juliansyah 2013.) dengan judul Implementasi Kebijakan Pemutakhiran Administrasi Pemilih dalam Pemilihan Umum Gubernur dan Wakil Gubernur Tahun 2007 menunjukkan bahwa implementasi kebijakan pemutakhiran administrasi data dan daftar pemilih belum berjalan efektif. Hal ini dapat dilihat dari masih terdapat data pemilih ganda dan membengkaknya jumlah pemilih di beberapa TPS; (2) Penelitian (Anusapati, 2014) dengan judul Kinerja Aparatur Komisi Pemilihan Umum Kabupaten Kubu Raya menunjukkan bahwa kinerja aparatur KPU Kabupaten Kubu Raya belum sesuai dengan harapan; (3) Penelitian Jani dengan judul Tinjauan tentang Kinerja Komisi Pemilihan Umum Daerah dalam Pelaksanaan Pemilu Presiden dan Wakil Presiden Tahun 2014 di Kabupaten Paser menunjukkan bahwa kinerja yang dilakukan oleh Komisi Pemilihan Umum Kabupaten Paser dalam Pelaksanaan Pemilihan Presiden dan Wakil Presiden cukup maksimal; (4) Penelitian (Lumingkewas 2015) dengan judul Kinerja Komisi Pemilihan Umum dalam Pemilihan Umum Legislatif (Studi di Kabupaten Minahasa Selatan) menunjukkan bahwa Komisi Pemilihan Umum belum melaksanakan tugasnya secara paripurna, sehingga perlu dilakukan koordinasi dengan pihak-pihak terkait yakni pemerintah Kabupaten Minahasa Selatan, TNI/POLRI, tokohtokoh masyarakat, dan pers, untuk membantu kinerja komisi pemilihan umum menjadi lebih baik dan melaksanakan tugasnya secara paripurna; dan (5) Penelitian (Halawa \& Adiwidjaja, 2016) dengan judul Analisis Kinerja Komisi Pemilihan Umum (KPU) Kabupaten Malang dalam Sosialisasi Menghadapi Pemilihan Kepala Daerah (Pilkada) Serentak Tahun 2015 menunjukkan bahwa kinerja yang dilakukan KPU Kabupaten Malang dalam menghadapi pemilihan kepala daerah serentak tahun 2015 telah berjalan dengan optimal baik dari perumusan kebijakan maupun dalam implementasi pemilihan Kepala Daerah tersebut.

\section{Metode Penelitian}

Penelitian ini menggunakan jenis penelitian kualitatif, yaitu metode penelitian yang banyak digunakan untuk meneliti pada kondisi objek yang alamiah (natural setting), yang dalam hal ini fenomena apa adanya pada subjek penelitian Kinerja Komisi Pemilihan Umum (KPU) Kabupaten Sintang. Teknik pengumpulan data yang digunakan adalah wawancara dan kajian dokumentasi.

Wawancara dilakukan dengan menggunakan pedoman yang sudah disiapkan, sedangkan pengumpulan dokumentasi terkait kegiatan pemutakhiran data dan penyusunan daftar pemilih yang sudah dilakukan. Adapun responden yang dipilih merupakan responden yang benar-benar mengalami kejadian, dalam pemutakhiran data dan penyusunan daftar pemilih yaitu Ketua KPU Kabupaten Sintang, Anggota KPU Kabupaten Sintang yang membidangi Divisi Data dan Informasi, Kepala Sub Bagian Program dan Data KPU Kabupaten Sintang, Operator Sistem Informasi Data Pemilih 
Kinerja Komisi Pemilihan Umum (KPU) Kabupaten Sintang dalam Pemutakhiran Data dan Penyusunan Daftar Pemilih Pemilihan Gubernur dan Wakil Gubernur Kalimantan

Barat Tahun 2018

(SIDALIH), Ketua PPK Sintang, Ketua PPS Desa Merti Guna, dan Ketua Panwaslu Kabupaten Sintang.

\section{Hasil dan Pembahasan \\ Kualitas Pekerjaan}

KPU Kabupaten Sintang merupakan penyelenggara Pemilihan Gubernur dan Wakil Gubernur Kalimantan Barat di Kabupaten Sintang, dengan memperhatikan Peraturan KPU serta petunjuk teknis yang dikeluarkan oleh KPU Provinsi Kalimantan Barat. KPU Kabupaten Sintang bekerja berdasarkan regulasi. Ukuran berkualitas atau tidaknya pekerjaan yang dilakukan KPU Kabupaten Sintang dapat dilihat dari pekerjaan yang dilakukan dibandingkan dengan regulasi yang ada.

Dalam pemutakhiran data dan penyusunan daftar pemilih, KPU Kabupaten Sintang berpedoman pada regulasi yang ada, yaitu Peraturan KPU Nomor 2 Tahun 2017 tentang Pemutakhiran Data dan Penyusunan Daftar Pemilih dalam Pemilihan Gubernur dan Wakil Gubernur, Bupati dan Wakil Bupati, serta Walikota dan Wakil Walikota. Dalam peraturan tersebut telah dijelaskan secara rinci proses yang dilakukan KPU Kabupaten dalam pelaksanaan teknis di lapangan, sehingga jika peraturan tersebut dilaksanakan, maka data pemilih yang dihasilkan pasti akurat.

Menurut (Abdullah, 2009) menyatakan bahwa ketidakakuratan data pemilih/DPT disebabkan oleh beberapa faktor, antara lain: (a) belum tertatanya dengan baik data kependudukan, yang mana hal ini merupakan wewenang dan tanggung jawab Pemerintah, dalam hal ini Kementerian Dalam Negeri beserta jajarannya; (b) pemutakhiran data/verifikasi data pemilih tidak dilakukan oleh KPU beserta jajarannya dengan baik; dan (c) masyarakat, dalam hal ini calon pemilih tidak berusaha secara aktif agar mereka tercantum dalam Daftar Pemilih Tetap.

Dilihat dari DPT yang dihasilkan, dapat dikatakan kualitas kinerja KPU Kabupaten Sintang dalam pemutakhiran data dan penyusunan daftar pemilih Pemilihan Gubernur dan Wakil Gubernur Kalimantan Barat Tahun 2018 sudah cukup baik. Hal ini dapat dinilai dari tidak banyaknya persoalan-persoalan yang mengemuka berkaitan daftar pemilih pada saat pelaksanaan pemungutan dan perhitungan suara. Selain itu, KPU Kabupaten Sintang telah melaksanakan regulasi yang ditetapkan dengan sebaikbaiknya, sehingga menghasilkan kualitas kinerja yang tinggi. Sebagaimana diungkapkan oleh (Dwiyanto, 2003) yang menjelaskan bahwa penilaian kinerja birokrasi publik tidak cukup dilakukan dengan menggunakan indikator yang melekat pada birokrasi itu, seperti efisiensi dan efektivitas, tetapi juga harus dilihat dari indikator-indikator yang melekat pada pengguna jasa, seperti kepuasan pengguna jasa, akuntabilitas, dan responsivitas. Penilaian kinerja dari sisi pengguna jasa menjadi sangat penting karena birokrasi publik juga muncul karena tujuan dan misi birokrasi publik sering kali bukan hanya memiliki stakeholder yang banyak dan memiliki kepentingan yang sering berbenturan satu sama lainya yang menyebabkan birokrasi publik 
mengalami kesulitan untuk merumuskan misi yang jelas. Akibatnya, ukuran kinerja organisasipublik di mata para stakeholders juga berbeda-beda.

\section{Ketepatan}

Dari pelaksanaan tahapan pemutakhiran data dan penyusunan daftar pemilih, semua berjalan sesuai dengan jadwal yang telah ditetapkan. Dimulai dari penyusunan Daftar Pemilih oleh KPU Kabupaten untuk disampaikan kepada PPDP melalui PPS yang dilakukan mulai tanggal 30 Desember 2017 s.d. 19 Januari 2018, kemudian kegiatan Pencocokan dan Penelitian (Coklit) oleh PPDP tanggal 20 Januari s.d. 18 Februari 2018, Rekapitulasi Daftar Pemilih Hasil Pemutakhiran (DPHP) oleh PPS, PPK, dan oleh KPU Kabupaten untuk ditetapkan sebagai Daftar Pemilih Sementara (DPS) tanggal 10 s.d. 16 Maret 2018. Setelah ditetapkannya DPS, PPS mengumumkan DPS tersebut di tempat-tempat strategis untuk diberikan masukan dan tanggapan dari masyarakat. DPS Hasil Perbaikan ditetapkan menjadi DPT oleh KPU Kabupaten pada tanggal 18 April 2019 (di jadwal 13 s.d. 19 April 2018). Sebagaimana wawancara dengan Anggota KPU Kabupaten Sintang yang membidangi Divisi Data dan Informasi KPU Kabupaten Sintang, yang menyatakan bahwa: "semua jadwal yang telah ditetapkan oleh KPU maupun KPU Provinsi telah dilaksanakan dengan baik oleh KPU Kabupaten Sintang. Sejak penyusunan Daftar Pemilih, Coklit, DPS, hingga DPT, jadwal tersebut disosialisasikan ke semua stakeholder, sehingga mereka semua dapat mengontrol jadwal yang telah ditetapkan".

Dari segi ketepatan, setiap tahapan yang dilaksanakan KPU Kabupaten Sintang berpedoman pada Tahapan, Program, dan Jadwal yang sudah ditetapkan oleh KPU. (Wibowo, 2014) menjelaskan bahwa pengukuran terhadap kinerja perlu dilakukan untuk mengetahui apakah selama pelaksanaan kinerja terdapat deviasi dari rencana yang telah ditentukan, atau apakah kinerja dapat dilakukan sesuai jadwal waktu yang ditentukan, atau apakah hasil kinerja telah tercapai sesuai dengan yang diharapkan. Untuk melakukan penilaian tesebut diperlukan kemampuan untuk mengukur kinerja sehingga diperlukan adanya ukuran kinerja. Dengan kondisi ini, ketepatan waktu pekerjaan menjadi hal mendasar yang harus dipenuhi oleh KPU Kabupaten Sintang dalam pemutakhiran data dan penyusunan daftarpemilih.

\section{Inisiatif}

Tahap pendaftaran pemilih merupakan tahap yang penting terkait dengan hak warga negara untuk dapat berpartisipasi dalam pemilu sekaligus parameter awal dari demokrasi prosedural. Setidaknya ada dua hal penting yang harus diperhatikan sebagai penyelenggara pemilu dalam pendaftaran pemilih yaitu teknik pendaftaran dan syarat untuk dapat didaftar sebagai pemilih. Teknik pendaftaran pemilih pada umumnya dapat dibedakan antara stelsel aktif dan stelsel pasif. Stelsel aktif yaitu penyelenggara pemilu menjadi pihak yang pasif untuk melakukan pendaftaran pemilih. Pemilih yang telah memenuhi syarat aktif mendaftarkan diri ke penyelenggara pemilu. Teknik stelsel pasif adalah kebalikan dari teknik stelsel aktif. Pada stelsel pasif, penyelenggara pemilu aktif 
Kinerja Komisi Pemilihan Umum (KPU) Kabupaten Sintang dalam Pemutakhiran Data dan Penyusunan Daftar Pemilih Pemilihan Gubernur dan Wakil Gubernur Kalimantan

Barat Tahun 2018

melakukan pendaftaran kepada warga negara yang telah memenuhi syarat untuk didaftar sebagai pemilih. Sementara itu, warga negara atau pemilih bersifat menunggu pendaftaran yang dilakukan penyelenggara pemilu.

Dalam penyelesaian masalah yang dihadapi, KPU Kabupaten Sintang menggunakan prinsip keputusan kolektif kolegial. Dengan model kepemimpinan ini, setiap persoalan yang timbul diputuskan secara bersama (kolektif) melalui rapat pleno. Seorang ketua hanya berfungsi sebagai pengarah dalam menentukan kebijakan yang akan diambil, bukan penentu akhir kebijakan tersebut. Selain itu, dalam menghadapi persoalan berkaitan dengan masalah daftar pemilih, KPU Kabupaten Sintang selalu melibatkan berbagai pihak agar kualitas data pemilih dapat dipertanggungjawabkan.

Hasil penelitian menunjukkan bahwa inisiatif KPU Kabupaten Sintang dalam memecahkan persoalan berkaitan dengan Pemutakhiran Data dan Penyusunan Daftar Pemilih dalam Pemilihan Gubernur dan Wakil Gubernur Kalimantan Barat Tahun 2018 sudah cukup baik. Hal ini terlihat dari responsivitas KPU Kabupaten Sintang dalam menanggapi masukan dan tanggapan masyarakat serta keterlibatan stakeholder dalam setiap pengambilan keputusan KPU Kabupaten Sintang proses penyusunan daftar pemilih yang berkualitas. Apa yang dilakukan KPU Kabupaten Sintang sudah sesuai dengan definisi dari pelayanan publik menurut Keputusan Menteri Pendayagunaan Aparatur Negara Nomor 63/Kep./M.PAN/7/2003 yang menyatakan bahwa pelayanan publik dipahami sebagai segala kegiatan layanan yang dilaksanakan oleh instansi pemerintah sebagai upaya pemenuhan kebutuhan orang, masyarakat, instansi pemerintah, dan badan hokum sebagai pelaksanaan ketentuan peraturan perundangundangan.

\section{Kemampuan}

Kemampuan penyelenggara Pemilu dalam melaksanakan pekerjaan dapat dilihat dari segi profesionalisme. Profesionalisme mempunyai arti seorang yang terampil, andal, dan sangat bertanggung jawab dalam menjalankan tugas atau profesinya. Seseorang layak dianggap profesional dalam bidang pekerjaan jika: (a) memiliki kemampuan atau keterampilan dalam menggunakan peralatan yang berhubungan dengan bidang pekerjaan; (b) memiliki ilmu dan pengalaman dalam menganalisis; (c) bekerja di bawah disiplin kerja; (d) mampu melakukan pendekatan disipliner; (e) mampu bekerja sama; serta (f) cepat tanggap terhadap masalah.

Pekerjaan KPU Kabupaten Sintang berkaitan dengan panitia yang berada di bawahnyayang biasa disebut badan ad hoc, yaitu Panitia Pemilihan Kecamatan (PPK), Panitia Pemungutan Suara (PPS), Petugas Pemutakhiran Data Pemilih (PPDP), dan Kelompok Penyelenggara Pemungutan Suara (KPPS). Semua panitia penyelenggara tersebut memberikan andil yang besar terhadap kualitas penyelenggaraan pemilu. Setiap personil yang ada harus dapat bekerja dengan profesional dan tentunya didukung oleh integritas pribadi yang merupakan penopang dalam terciptanya pemilu yang 
berkualitas. Dalam kaitan pemutakhiran data dan penyusunan daftar pemilih, badan $a d$ hoc yang terlibat adalah PPK, PPS, dan PPDP.

Berkaitan dengan kemampuan PPDP, Ketua PPK Kecamatn Sintang menyatakan bahwa jumlah PPDP adalah 1 (satu) orang untuk satu TPS. Dengan waktu Coklit selama 1 bulan, hal ini tidak masalah, tergantung pada individu petugasnya, apakah serius bekerja dalam pelaksanaan Coklit atau tidak. KPU melalui PPK dan PPS selalu memberikan motivasi agar PPDP bekerja dengan baik. Memang hal ini agak berat, karena rata-rata PPDP adalah ketua RT yang notabene merasa sudah menguasai wilayah dan penduduk, jadi kadang-kadang mereka agak mengabaikan prosedur yang sudah ditetapkan. Misalnya, dalam pelaksanaan coklit yang harusnya dilakukan door to door tetapi kenyataan di lapangan ada laporan bahwa PPDP hanya melakukan pendataan di rumah dengan meneliti nama-nama dari daftar yang diberikan.

Berdasarkan dokumen yang ada, anggota PPDP yang melakukan pemutakhiran data hanya sebagian kecil yang berkualifikasi sarjana dan ahli madya. Hal inilah yang mempengaruhi kinerja mereka dalam pemutakhiran data pemilih sehingga kurang maksimal memahami mekanisme kerja yang sudah ditetapkan. Apalagi mayoritas dari anggota PPDP belum cukup memiliki pengalaman dan pemahaman terkait hal yang harus dilakukan dalam pemutakhiran, sekalipun telah dilakukan bimbingan teknis oleh KPU Kabupaten melalui PPK dan/atau PPS.

Hasil penelitian menunjukkan bahwa faktor kemampuan SDM di tingkat ad hoc dapat ditutupi dengan komunikasi yang efektif dan profesionalisme dari KPU Kabupaten Sintang dalam menyampaikan regulasi dan mengoordinasikan seluruh tahapan. Pola-pola koordinasi yang baik dilakukan untuk menutupi kekurangankekurangan yang terjadi dalam hal kemampuan pemahaman PPDP maupun PPS dan PPK dalam pelaksanaan tahapan. Hal ini sesuai dengan apa yang diungkapkan oleh (Simamora, 2012) yang menyatakan bahwa kinerja (performance) dipengaruhi oleh tiga faktor yaitu (1) faktor individual yang terdiri dari: kemampuan dan keahlian, latar belakang, dan demografi; (2) faktor psikologis yang terdiri dari: persepsi, attitude, personality, pembelajaran, dan motivasi; serta (3) faktor organisasi yang terdiri dari: sumberdaya, kepemimpinan, penghargaan, struktur, dan job design.

\section{Komunikasi}

Pola komunikasi yang dibangun KPU Kabupaten Sintang dalam pemutakhiran data dan penyusunan daftar pemilih pada Pemilihan Gubernur dan Wakil Gubernur Kalimantan Barat Tahun 2018 di Sintang sudah berjalan dengan baik. Hal ini dapat dilihat dari respons stakeholder, baik dalam kegiatan rapat koordinasi maupun rapatrapat penetapan DPS dan DPT. Hanya memang perlu dicari solusi berkaitan dengan masalah partisipasi masyarakat dalam ikut aktif melakukan pengecekan daftar pemilih yang sudah diumumkan. Upaya-upaya yang dilakukan KPU Kabupaten Sintang sebenarnya sudah cukup intens dalam sosialisasi terhadap pengumuman DPS, tetapi memang kesadaran masyarakat dalam hal ini yang masih kurang. Untuk itu diperlukan pemahaman bersama agar selain penyelenggara (KPU dan Bawaslu), masyarakat 
Kinerja Komisi Pemilihan Umum (KPU) Kabupaten Sintang dalam Pemutakhiran Data dan Penyusunan Daftar Pemilih Pemilihan Gubernur dan Wakil Gubernur Kalimantan

Barat Tahun 2018

(termasuk tim kampanye pasangan calon) juga harus aktif berpartisipasi dalam setiap tahapan pemilihan, terutama dalam pemutakhiran data dan penyusunan daftar pemilih.

Berdasarkan hasil wawancara, faktor kerja sama merupakan faktor penentu terselenggaranya tahapan pemutakhiran data dan penyusunan daftar pemilih yang sebagaimana diharapkan bersama. Tentu kerja sama ini bukan hanya sebatas komisioner dengan sekretariat, tapi juga bagaimana kerja sama terbangun antara KPU, PPK, PPS, dan PPDP, juga antara KPU dengan Pengawas Pemilihan dan seluruh stakeholder lainnya. Dengan komunikasi yang dibangun oleh KPU kepada seluruh stakeholder ini, pemutakhiran data pemilih dapat terlaksana dengan baik dan menghasilkan data yang akurat.

\section{Kesimpulan}

Berdasarkan hasil penelitian dapat disimpulkan sebagai berikut. (1) Kualitas Daftar Pemilih Tetap (DPT) Pemilihan Gubernur dan Wakil Gubernur Kalimantan Barat Tahun 2018 di Kabupaten Sintang sudah cukup baik; (2) Ketepatan dalam proses pemutakhiran data dan penyusunan daftar pemilih di KPU Kabupaten Sintang sudah berjalan sesuai dengan tahapan yang sudah ditetapkan; (3) Inisiatif KPU Kabupaten Sintang dalam proses pemutakhiran data dan penyusunan daftar pemilih sudah baik; (4) Kemampuan KPU Kabupaten Sintang dalam pemutakhiran data dan penyusunan daftar pemilih masih kurang maksimal terutama pada badan penyelenggara ad hoc; dan (5) Komunikasi yang dibangun KPU Kabupaten Sintang sudah cukup baik.

Dari hasil penelitian yang sudah dilakukan dapat disampaikan saran-saran untuk KPU Kabupaten Sintang, yaitu: (a) melakukan sosialisasi yang massif, guna memastikan semua masyarakat dan stakeholder mengetahui dan ikut berpartisipasi dalam kegiatan tersebut; (b) melakukan rekrutmen penyelenggara ad hoc dengan teliti, terutama untuk Petugas Pemutakhiran Data Pemilih (PPDP); dan (c) komunikasi yang sudah cukup baik antar-stakeholder yang terlibat agar ditingkatkan untuk membangun kesepemahaman. Untuk Pemerintah Kabupaten Sintang agar dapat: (a) memberikan akses yang memadai untuk KPU Kabupaten guna mencermati data kependudukan yang ada dalam database Dinas Kependudukan dan Catatan Sipil, serta (b) memfasilitasi kegiatan pemutakhiran data dan penyusunan daftar pemilih secara maksimal dengan ikut mensosialisasikannya kepada masyarakat. Untuk Panwaslu Kabupaten Sintang diharapkan (a) melakukan pengawasan yang ketat dalam kegiatan coklit dan penyusunan daftar pemilih, dan (b) mengomunikasikan temuan-temuan yang ada di lapangan agar dilakukan pencermatan bersama. Untuk Partai Politik, Pasangan Calon, dan Tim Kampanye serta masyarakat agar aktif memantau proses pemutakhiran data dan penyusunan daftar pemilih dengan mengecek data dan memberikan masukan jika data yang ada beluma kurat. 


\section{Bibliography}

Abdullah, R. (2009). Mewujudkan pemilu yang lebih berkualitas: pemilu legislatif. Rajawali Pers.

Anusapati, E. (2014). Kinerja Aparatur Komisi Pemilihan Umum Kabupaten Kubu Raya. Tanjungpura University.

Dwiyanto, A. (2003). Reformasi tata pemerintahan dan otonomi daerah. Pusat Studi Kependudukan dan Kebijakan, Universitas Gadjah Mada.

Halawa, M., \& Adiwidjaja, I. (2016). Analisis Kinerja Komisi Pemilihan Umum (Kpu) Kabupaten Malang dalam Sosialisasi Menghadapi Pemilihan Kepala Daerah (Pilkada) Serentak Tahun 2015. Jisip: Jurnal Ilmu Sosial Dan Ilmu Politik, 5(3).

Ilyas, Y. (2012). Kinerja, Teori, Penilaiandan Penelitian. Pusat Kajian Ekonomi Kesehatan FKM Universitas Indonesia.

Juliansyah, E. (n.d.). IMPLEMENTASI KEBIJAKAN PEMUTAKHIRAN ADMINISTRASI PEMILIH DALAM PEMILIHAN GUBERNUR DAN WAKIL GUBERNUR. JIANA (Jurnal Ilmu Administrasi Negara), 12(3), 199-208.

Lumingkewas, F. (n.d.). R.(2015). Kinerja Komisi Pemilihan Umum Dalam Pemilihan Umum Legislatif: Studi Di Kabupaten Minahasa Selatan. Skripsi Universitas Ratulangi.

Simamora, H. (2012). Manajemen Sumber Daya Manusia. Edisi 1 (STIE YKPN). STIE YKPN Yogyakarta.

Wibowo. (2014). Manajemen Kinerja. Raja Grafindo Persada.

Keputusan Menpan No. 63/Kep./M.PAN/7/2003, Paragraph I, butir c tentang Pedoman Umum Penyelenggaraan Layanan Publik.

Mangkunegara, Anwar, Prabu. 2017. Manajemen Sumber Daya Manusia Perusahaan. Bandung: Remaja Rosdakarya.

Martoyo. 2014. Kinerja Aparatur Komisi Pemilihan Umum Kabupaten Kubu Raya. Jurnal Program Magister Ilmu Sosial Universitas Tanjungpura Pontianak, Vol. 4, No. 0004 Tahun 2014.

Peraturan KPU Nomor 2 Tahun 2017 tentang Pemutakhiran Data dan Penyusunan Daftar Pemilih dalam Pemilihan Gubernur dan Wakil Gubernur, Bupati dan Wakil Bupati, dan/atau Walikota dan Wakil Walikota 